\title{
Blood Glucose, Insulin and Inorganic Phosphorus in Healthy and Ketotic Dairy Cows after Intravenous Infusion of Glucose Solution
}

\author{
Radojica Djoković ${ }^{1}$, Horea Šamanc ${ }^{2}$, Zoran Ilić ${ }^{3}$, Vladimir Kurćubić \\ ${ }^{1}$ Department of Animal Science, Faculty of Agronomy, Čačak University of Kragujevac, Serbia \\ ${ }^{2}$ Department for Diseases of Ruminants and Pigs, Faculty of Veterinary Medicine, University of Belgrade \\ ${ }^{3}$ Department of Animal Science, Faculty of Agronomy, Zubin Potok University of Priština, Serbia
}

Received August 20, 2008

Accepted February 9, 2009

\begin{abstract}
The aim of the present study was to determine the degree of blood glucose utilization by peripheral tissue on the basis of changes in blood concentrations of glucose, insulin and inorganic phosphorus in healthy $(\mathrm{n}=10)$ and ketotic cows $(\mathrm{n}=10)$ after intravenous infusion of glucose solution. Blood samples were taken in both groups of examined cows at the following time intervals: just before (time 0) and 30, 60, 120, 180 and $240 \mathrm{~min}$ after intravenous infusion of a total of $500 \mathrm{ml}$ of $50 \%$ of glucose solution. Glucose and insulin blood serum values in both groups of cows increased significantly within 30 and $60 \mathrm{~min}$ of the experiment $(p<0.05)$. Significantly lower values $(p<0.05)$ of insulin in blood serum of ketotic cows compared to the healthy ones were established within 30 and $60 \mathrm{~min}$ of the test. This indicated that the ability of beta cells of the endocrine pancreas to release insulin is reduced in cows suffering from ketosis. After intravenous infusion of glucose, it was established that values of inorganic phosphorus were decreased in blood in both groups of cows. Within 180 and $240 \mathrm{~min}$ of testing there was a significant decrease $(p<0.05)$ in the blood value of inorganic phosphorus in ketotic cows compared to the healthy ones. This is linked with the active entry of glucose into the glucolytic pathway of peripheral tissues. It can thus be concluded that there is a higher degree of blood glucose utilization by peripheral tissues in ketotic cows.
\end{abstract}

Ketosis, glucose utilization, glucolytic pathway, peripheral tissue

Optimal supply of glucose to the liver and mammary gland plays an important role in preserving the health of dairy cows in the early stage of lactation. The first metabolic change in primary ketosis in dairy cows in early lactation is hypoglycaemia. It causes serious metabolic changes in the body, manifested through lipid mobilization from body reserves and ketogenesis and lipogenesis in the liver (Veenhuizen et al. 1991; Vazquez-Anon et al.1994).

The glucose tolerance test is used for estimating the ability of the endocrine pancreas for synthesis and secretion of insulin in ruminants. The insulin concentration in blood is reduced in ketotic cows compared to healthy animals in early lactation, before and after infusion of a glucose solution (Hove 1978; De Cupere et al. 1991; Sakai et al. 1996; S a manc et al. 1996). Similar results have been reported by other authors (Peters and Elliot 1984; Šamanc et. al. 1996; Djoković et al. 2007), after intravenous infusion of propionate solution, because propionic acid directly stimulates pancreatic secretion of insulin in ruminants.

During the glucose tolerance test, it is very difficult to estimate on the basis of glycaemia whether the metabolic disorder was induced by liver disease or hypofunction of the endocrine pancreas. At the same time, an estimation of the concentration of inorganic phosphorus in blood can be helpful. Namely, the decrease of its concentration in blood after intravenous infusion of glucose is linked with the active utilization of glucose into the glycolytic pathway of peripheral tissue, while a considerably smaller amount of glucose is used for glycogenesis in the liver (Sakai et al. 1993; Gründberg et al. 2006; Djoković et al. 2007).

Address for correspondence:

MV Dr Radojica Djoković, associate professor

Department of Animal Science, Faculty of Agronomy, Čačak,

University of Kragujevac

Cara Dušana 34,32000 Čačak, Serbia
Phone $+38132 / 303400,303410$

Fax: +381 32/303 401

E-mail:djokovici@ptt.rs

http://www.vfu.cz/acta-vet/actavet.htm 
The aim of the present study was to determine the degree of blood glucose utilization by peripheral tissue on the basis of changes in blood concentrations of glucose, insulin and inorganic phosphorus in healthy and ketotic cows after intravenous infusion of glucose solution.

\section{Materials and Methods}

A total of ten healthy and ten ketotic cows were chosen from a Holstein dairy herd. The diagnosis of ketosis was made on the basis of clinical symptoms (reduced appetite, rumen atony, behavioural changes) and determined urinary ketone in high concentrations. The presence of ketone bodies in urine was examined by using the Lestradet test. Ketotic animals were included in the experiment 1-2 days after occurrence of clinical symptoms and before commencing medical treatment. Healthy cows did not show clinical symptoms of ketosis and urinary ketone bodies were not diagnosed in those cows. All animals were of similar body mass $(580 \mathrm{~kg}), 4-6$ years old, with an average of 2.8 lactations with a mean milk yield of 7,8201 (calculated over 305 days) in the previous lactation and were all in the earliest stage of lactation (7-14 days post partum). The diet was prepared to meet the energy needs of animals in early lactation. Both groups were fed the same diet consisting of $4 \mathrm{~kg}$ lucerne hay, $15 \mathrm{~kg}$ maize silage (30\% DM), $8 \mathrm{~kg}$ lucerne haylage, $4 \mathrm{~kg}$ maize ear silage $(68 \% \mathrm{DM}), 2 \mathrm{~kg}$ dry sugar beet pulp, $2 \mathrm{~kg}$

Table 1. Nutrient contents in daily ration for dairy cows with milk yield 35 litres

\begin{tabular}{|l|c|}
\hline Dry matter (DM), Kg & 21.5 \\
\hline Net energy of lactation (NEL), MJ & 153.2 \\
\hline Crude protein (CP), \% DM & 18.3 \\
\hline Rumen non-degradable protein (RUP), \% CP & 39.69 \\
\hline Fat, \% DM & 4.92 \\
\hline Fibre, \% DM & 17.2 \\
\hline Acid detergent fibre (ADF), \% DM & 22.6 \\
\hline Neutral detergent fibre (NDF), \% DM & 37.16 \\
\hline
\end{tabular}
extruded soybean grains, $4.5 \mathrm{~kg}$ concentrate $(30 \% \mathrm{CP})$. Dietary nutrient content for dairy cows with milk production of 351 is given in Table 1.

The test was carried out in the morning at 9:00 $\mathrm{h}$ about $3 \mathrm{~h}$ after feeding. A solution of glucose $(500 \mathrm{ml}$ of $50 \%$; Pharmacy: Zdravlje, Leskovac) was injected intravenously during $5 \mathrm{~min}$ into the jugular vein of each animal. Blood samples were taken from the opposite jugular vein before and $30,60,120,180$ and 240 min after injection.

Portions of blood samples were allowed to coagulate spontaneously at room temperature. The serum was then decanted and centrifuged at $1,000 \mathrm{~g}$ and preserved at $-18{ }^{\circ} \mathrm{C}$ until analysis.

Glucose concentrations were determined in fresh whole blood using Dextrostix tracks and the values were read on an Eyeton Refractans colorimeter. Blood serum concentrations of insulin were determined using heterologous radioimmunoassay (RIA) method. Blood serum concentrations of inorganic phosphorus were determined using the UV method (023200) reagent Serbolab (Serbia). Biochemical indicators in the blood serum were assayed at the laboratory of the Institute for the Application of Nuclear Energy in Agriculture (INEP) Zemun.

The mean values and standard deviations (SD) for each group of cows were calculated at each time interval in testing. The differences between the group means and within each treatment were evaluated by analysis of variance according to ANOVA procedure and significance was estimated by the least significance difference (LSD) test at probability levels of $p<0.05$ and $p<0.01$ (Microsoft STATISTICA ver.5.0, Stat. Soft. Inc. 1995).

\section{Results}

Changes in glucose, insulin and inorganic phosphorus values in the peripheral circulation of the cows given glucose intravenously are shown in Figs 1, 2 and 3.

The initial blood glucose values were lower in ketotic cows $\left(1.69 \pm 0.35 \mathrm{mmol} \cdot \mathrm{l}^{-1}\right)$ than in healthy cows $\left(3.03 \pm 0.29 \mathrm{mmol} \cdot \mathrm{l}^{-1} ; p<0.05\right)$. Glucose injection led to a significant increase in glycaemia within 30,60 and 120 min of the experiment in both groups of cows $(p<0.05)$, which peaked within 30 min and then slowly declined. In the group of cows with ketosis, the mean blood glucose value was significantly lower than in the healthy group of cows within 30 min of the experiment $(p<0.01)$. The blood glucose value in these cows then decreased to a value lower than in healthy cows, returning to a concentration within the physiological limit at the end of the experiment $\left(2.86 \pm 0.53 \mathrm{mmol} \cdot \mathrm{l}^{-1}\right)$.

Mean initial blood insulin values were slightly, but not significantly lower $(p>0.05)$ in the ketotic group $\left(74.45 \pm 18.75 \mathrm{pmol} \cdot \mathrm{l}^{-1}\right)$ than in the control group of cows $(102.37 \pm 27.78$ pmol $\left.\cdot 1^{-1}\right)$. The glucose injection led to a significant increase in insulinaemia within 30 and 60 min of the experiment in both groups of cows $(p<0.05)$. Namely, the value increased 


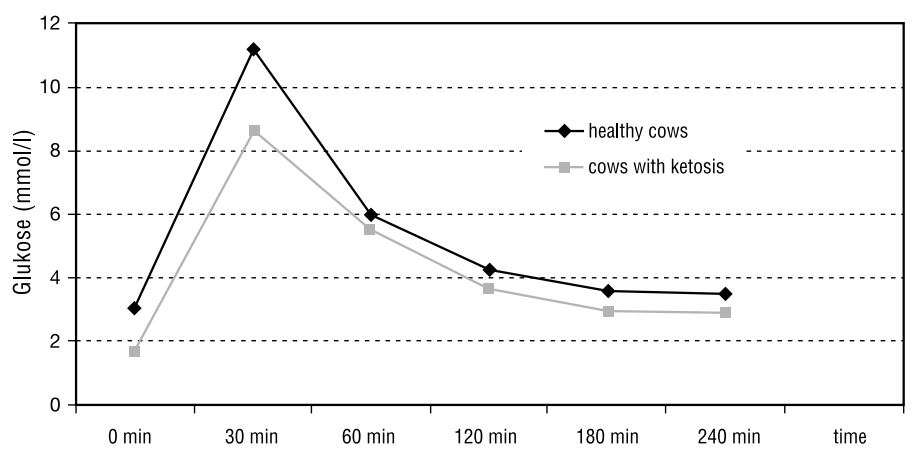

Fig. 1. Changes in blood glucose $\left(\mathrm{mmol}^{1-1} \mathrm{1}^{-1}\right)$ of healthy and cows with ketosis after intravenous infusion of glucose solution

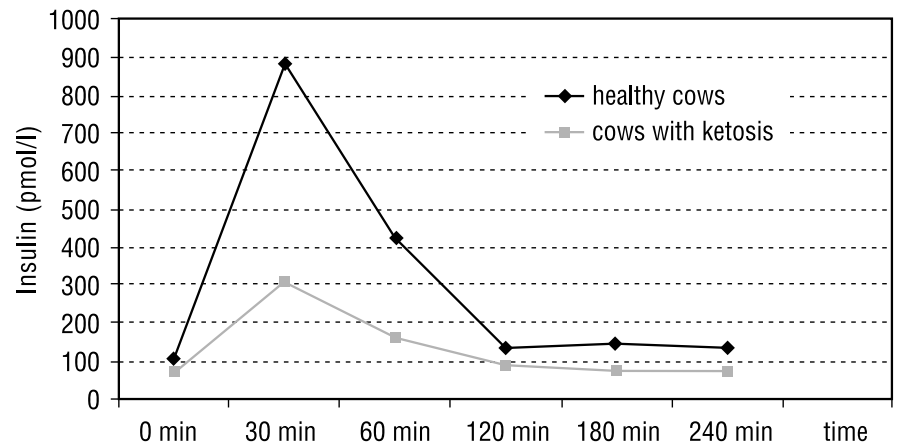

Fig. 2. Changes in blood insulin $\left(\mathrm{pmol}^{1} \mathrm{1}^{-1}\right)$ of healthy and cows with ketosis after intravenous infusion of glucose solution

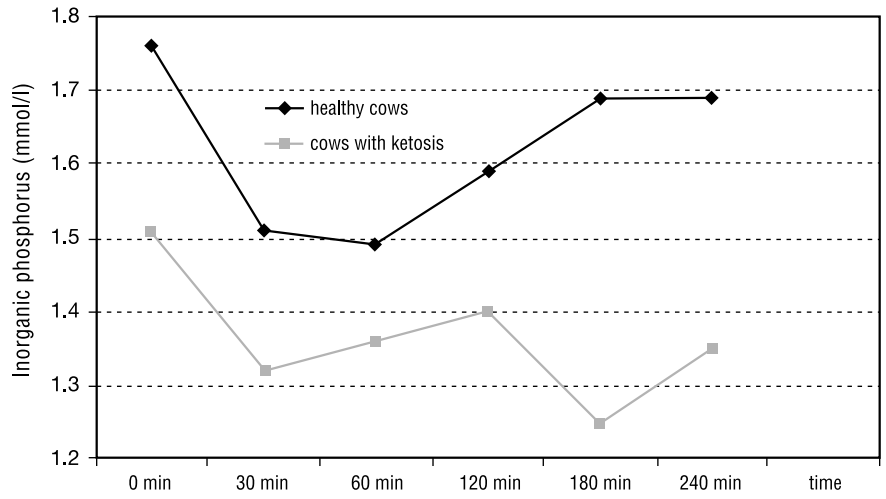

Fig. 3. Changes in blood inorganic phosphorus $\left(\mathrm{mmol} \cdot 1^{-1}\right)$ of healthy and cows with ketosis after intravenous infusion of glucose solution

to $881.74 \pm 347.60 \mathrm{pmol} \cdot \mathrm{l}^{-1}$ within $30 \mathrm{~min}$ in healthy cows compared to $309.33 \pm 128.20$ pmol $\cdot 1^{-1}$ in ketotic cows $(p<0.01)$. This marked difference lasted for 60 min after glucose administration $(p<0.05)$, but the insulin response exceeded $120 \mathrm{~min}$ in both groups of cows. 
The inorganic phosphorus blood values in the healthy group of cows before the infusion of a glucose solution were $1.76 \pm 0.46 \mathrm{mmol} \cdot \mathrm{l}^{-1}$, whereas they were $1.51 \pm 0.26 \mathrm{mmol} \cdot \mathrm{l}^{-1}$ in ketotic cows, although not significantly lower $(p>0.05)$. After intravenous infusion of a glucose solution, a decrease of the inorganic phosphorus values in the blood in both groups of cows was determined during the test period $(p>0.05)$. Among the tested groups of cows, significant differences of the values of inorganic phosphorus in the blood were determined within 180 and $240 \mathrm{~min}$ of the test period $(p<0.05)$.

\section{Discussion}

The glucose tolerance test is used to estimate the functional ability of beta cells for the synthesis and release of insulin (Hove 1978; Sakai et al.1993; Sakai et al. 1996; Holtenius et al. 2003).

Glucose directly stimulates insulin secretion primarily by increasing the concentration of cytoplasmic calcium ions, the process depending on the ability of beta cells to transport the sugar into the cell and metabolise it. Apart from mannose, some amino acids and shortchain fatty acids (in ruminants) which act directly, beta cell function may be enhanced by cholinergic stimulation, the neuropeptide cholecystokinin, glucagon and gut hormones such as the gastric inhibitory peptide (Flatt et al. 1991).

The initial blood glucose values in healthy cows were within the physiological range of 2.5-4.2 $\mathrm{mmol} \cdot \mathrm{l}^{-1}$ (Radostits et al. 2000), whereas hypoglycaemia was determined in ketotic cows. In this study, the glucose injection led to an increase $(p<0.05)$ in glycaemia within 30,60 and 120 min of the experiment in both groups of cows. The fact that glucose values after intravenous administration showed similar increments and similar rates of decline in healthy and ketotic cows indicated that the mean glucose disposal was similar in both groups of animals. Thus, the pancreatic islets were subjected to almost identical glucose stimuli. These results are in accordance with the observations by Hove (1978) and Samanc et al. (1996).

The significant increase $(p<0.05)$ of blood insulin values in both groups of cows after the infusion of the glucose solution within 30 and $60 \mathrm{~min}$ of the test period, compared to the starting values, confirms the possibility of glucose to influence the synthesis and release of insulin from beta cells of the endocrine pancreas. Furthermore, a significantly lower $(p<0.05)$ value of insulin was estimated in the blood of ketotic cows, compared to the healthy ones, within 30 and $60 \mathrm{~min}$ of the test. The low secretory responses of insulin in ketotic cows are therefore probably the result of a low secretory capacity for insulin of the pancreas, developed during the days or weeks of hypoglycaemia that regularly accompanies high ketosis. These results show the preserved function (relative insufficiency) of beta cells of the endocrine pancreas of ketotic cows. Other authors have reported similar results indicating that blood glucose is utilised for energy purposes by peripheral tissues (Peters and Elliot 1984; De Cupere et al. 1991; Sakai et al. 1993; Sakai et al.1996; Holtenius et al. 2003).

In healthy cows, the largest decrease of the value of inorganic phosphorus was determined within $60 \mathrm{~min}$ of the testing. It was $15.4 \%$ lower than the starting value, although not significantly lower $(p>0.05)$. On the other hand, the blood value of inorganic phosphorus within 180 min of testing was determined as lower $(p>0.05)$ in ketotic cows, which was $16.8 \%$ lower than the starting value.

The decrease $(p<0.05)$ of the value of inorganic phosphorus in the blood of ketotic cows compared to the healthy ones after 180 and 240 min of infusing glucose could be a sign of the increased utilisation of glucose in blood by the peripheral tissue in ketotic cows. These results are in accordance with the findings of Djoković et al. (2007). It can thus be concluded that there is a higher degree of blood glucose utilisation by peripheral tissues in ketotic cows. Further thorough investigations should confirm the obtained results. 


\section{Hodnoty glukózy, inzulínu a anorganického fosforu v krevním séru zdravých dojnic a dojnic postižených ketózou po intravenózní infúzi glukózy}

Cílem práce bylo určit míru utilizace krevní glukózy periferními tkáněmi na základě změn koncentrace glukózy, inzulínu a anorganického fosforu v krvi zdravých $(\mathrm{n}=10)$ dojnic a krav postižených ketózou $(n=10)$ po intravenózní infúzi roztoku glukózy. Vzorky krve byly odebrány oběma skupinám dojnic v následujících časových intervalech: těsně před začátkem podávání roztoku cukru (v čase 0) a za 30, 60, 120, 180 a 240 min po

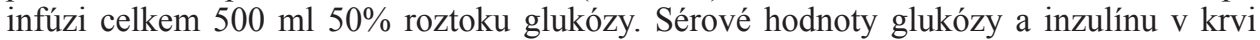
krav z obou zkoumaných skupin signifikantně vzrostly po 30 a 60 min experimentu $(p<0.05)$. Významně nižší hodnoty $(p<0.05)$ inzulínu byly nalezeny v krevním séru dojnic postižených ketózou ve srovnání se zdravými krávami za 30 a 60 min po podání glukózy. Tato skutečnost ukazuje na sníženou schopnost beta buněk pankreatu dojnic postižených ketózou uvolňovat inzulín. Po intravenózním podání roztoku glukózy byly zjištěny snížené hodnoty anorganického fosforu krvi u dojnic z obou skupin. Během 180 a 240 min od začátku podávání infuze glukózy bylo pozorováno významné snížení $(p<0.05)$ v krevních hodnotách anorganického fosforu u krav s ketózou v porovnání se zdravými krávami. Toto je spojeno s aktivním vstupem glukózy do glykolýzy v periferních tkáních. Z výsledků práce vyplývá, že dojnice trpící ketózou mají zvýšený stupeň utilizace glukózy v periferních tkáních než je tomu u zdravých krav.

\section{References}

De Cupere F, Muylle E, Van Den Hende C, Oyaert W 1991: Metabolic profile test in high yielding normal cows and in cows suffering from abomasal displacement. Boviner Practitioner 25: 129-130

Djoković R, Šamanc H, Nikolić Z, Bošković-Bogosavljević S 2007: Changes in blood values of glucose, insulin and inorganic phosphorus in healthy and ketotic dairy cows after intravenous infusion of propionate solution. Acta Vet Brno 76: 525-532

Flatt PD, Burnnet CR, Shibier O, Swanston-Flatt SK 1991: Direct and indirect actions of nutrients in the regulation of insulin secretion from the pancreatic b cells. Proc Nutr Soc 50: 559-566

Gründberg W, Morin DE, Drackley JK, Constable PD 2006: Effect of rapid intravenous administration of 50\% dextrose solution on phosphorus homeostasis in postparturient cows. J Vet Intern Med 20:1471-1478

Holtenius K, Agenas S, Delavaud C, Chilliard Y 2003: Effects of feeding intensity during the dry period. 2. Metabolic and hormonal responses. J Dairy Sci 86: 883-891

Hove K 1978: Insulin secretion in lactating cows. Responses to glucose infused intravenously in normal, ketonemic and starved animals. J Dairy Sci 61: 1407-1413

Peters JP, Elliot JN 1984: Endocrine changes with infusion propionate in the dairy cows. J Dairy Sci 67: 24552459

Radostits OM, Blood DC, Gay CC, Hinchcliff KW 2000: Veterinary Medicine, A Textbook of the Diseases of Cattle, Sheep, Pigs, Goats and Horses. Ninth Edition W.B. Saunders Company Ltd. London New York Philadelphia San Francisco St. Louis Sydney

Sakai T, Hamakawa T, Hamakawa M, Ogura K, Kubo S 1993: Therapeutic effects of simultaneous use of glucose and insulin in ketotic cows. J Dairy Sci 76: 109-114

Sakai T, Hamakawa M, Kubo S 1996: Glucose and Xylitol tolerance test for ketotic and healthy cows. J Dairy Sci 79: 372-377

Šamanc H, Nikolić AJ, Stojić V, Djoković R, Damjanović Z, Ivanov I 1996: Glucose tolerance and propionate loading tests in the assessment of endrocine pancreatic function in healthy and ketotic cows. Acta Vet Beograd 46, 5-6: 245-254

Vazquez-Anon M, Bertics S, Luck M, Grummer RR, Pinheiro J 1994: Peripartum liver triglyceride and plasma metabolites in dairy cows. J Dairy Sci 77: 1521-1528

Veenhuizen JJ, Drackley JK, Richard MJ, Sanderson TP, Miller LD, Young JW 1991: Metabolic changes in blood and liver during development and early treatment of experimental fatty liver and ketosis in cows. J Dairy Sci 74: $4238-4253$ 